\title{
Dry matter, Nutrient Uptake and Yield of Short Duration Pigeon pea (Cajanus cajan L.) Varieties under Drip Fertigation system
}

\author{
R. Jeyajothi ${ }^{1 *}$ and S. Pazhanivelan ${ }^{2}$ \\ ${ }^{1}$ Department of Agronomy, College of Agricultural Technology, Theni - 625 562, T.N., India \\ ${ }^{2}$ Department of Remote Sensing and GIS, TNAU, Coimbatore - 641 003, T.N., India \\ *Corresponding author
}

\section{A B S T R A C T}

Keywords

Drip fertigation, Dry matter production, Nutrient uptake rate, Pigeonpea and yield.

Article Info

Accepted:

28 September 2017

Available Online:

10 November 2017
Field experiment was conducted at Millet Breeding Station, Tamil Nadu Agricultural University, Coimbatore during 2015 and 2016 with the objective of Dry matter, Nutrient uptake and yield of short duration Pigeon pea (Cajanus cajan L.) varieties under Drip fertigation system. The experiment was laid out in strip plot design with three replications. The main plot treatments were allotted with three varieties viz., Co $(\operatorname{Rg}) 7$, APK 1 and VBN 3. The sub plot treatments comprised of three drip fertigation levels viz., $75 \%, 100$ $\%$ and 125\% RDF (@ 25:50:25 kg NPK ha ${ }^{-1}$ ) through WSF with Azophosmet and foliar spray of PPFM and drip fertigation at $100 \%$ RDF through WSF alone along with surface irrigation with conventional fertilizers. The effect of varieties and nutrient application methods (drip fertigation and soil application) the highest NPK uptake during kharif 2015 and summer $2016\left(187.32,17.04,107.4\right.$ and $\left.165.85,15.9,95.40 \mathrm{~kg} \mathrm{ha}^{-1}\right)$ dry matter production of (7042 and $6235 \mathrm{~kg} \mathrm{ha}^{-1}$ during kharif 2015 and summer 2016). The grain yield 1992 and $1758 \mathrm{~kg} \mathrm{ha}^{-1}$ were significantly observed under drip fertigation with $125 \%$ RDF through WSF with Azophosmet and foliar spray of 1\% PPFM. Among the pigeonpea varieties, Co (Rg)7 performed well compared to APK 1 and VBN 3 varieties.

\section{Introduction}

Pigeonpea is produced in all tropical and semi-tropical regions of the world and grown as an annual or as a perennial crop in 50 countries of Asia, Africa and the Carribean. In India, pigeonpea is grown in areas lying between $14^{\circ}$ and $28^{\circ} \mathrm{N}$ latitude at which majority of the world's pigeonpea is produced (Pramod et al., 2010). According to FAO statistics, pigeonpea is grown worldwide in an area of 4.23 m.ha. With a production and productivity of $4.68 \mathrm{~m} . t$. and $751 \mathrm{~kg}$ ha-1 respectively. India is the largest producer of pigeonpea accounting for about $80 \%$ of the total world pigeonpea production. In India, it occupies an area of 3.71 m.ha. with a production and a productivity of $2.78 \mathrm{~m}$.t. and $750 \mathrm{~kg} \mathrm{ha}^{-1}$ respectively (GoI, 2015). The demand for pulses is increasing due to increasing population and hence pigeonpea productivity has to be increased to meet the demand. Drip fertigation is the best option to increase the production and productivity of pigeonpea. Drip fertigation is a recent innovative cultural method, by which fertilizers are applied along with irrigation water through drip system to get higher fertilizer use efficiency besides increasing the crop yields. Pulses are an integral part of 
many diets across the globe and they have great potential to improve human health, conserve our soils, protect the environment and contribute to global food security. The United Nations declared 2016 as "International Year of Pulses" (IYP) to heighten public awareness of the nutritional benefits of pulses as part of sustainable food production aimed at food security and nutrition. The demand for pulses is increasing due to increasing population, and hence to meet the demand, pigeonpea productivity has to be increased. Drip irrigation is a technique which might help in increasing area under irrigation, productivity of crops and increase the water use efficiency (Tarawalie et al., 2012). The method of fertilizer application is very important in obtaining optimal use of fertilizer.

Fertilizers should be applied in a form that becomes available in synchrony with crop demand for maximum utilization of nutrient from fertilizers (Anitta Fanish and Muthukrishnan 2013). This will increase the amount of fertilizer used by the plant and reduce the amount lost by leaching. To meet out the requirement, the only way is to increase the production and productivity for that drip fertigation is the best option. Drip fertigation allows precise timing and uniform distribution of fertilizer nutrients, and is an efficient and agronomically sound method of providing soluble plant nutrients directly to the active plant root zone. Usually optimizing nutrient management with drip irrigation would require that attention be paid to soil nutrient dynamics, crop nutrient requirements, as well as soil and plant monitoring techniques.

\section{Materials and Methods}

Field experiment was conducted at Millet Breeding Station at Tamil Nadu Agricultural University, Coimbatore. The location is geographically situated at $11^{\circ} \mathrm{N}$ Latitude and $77^{\circ} \mathrm{E}$ longitude at an Altitude of $426.7 \mathrm{~m}$ above MSL.

Each plot was $40 \mathrm{~m}^{2}$ and contained 8 rows with 28 lines. Paired row planting system was adopted under drip irrigation with spacing of $90 / 30 \times 30 \mathrm{~cm}$. One lateral with inline dripper (discharge rate@ 4 lph) was laid at the centre of the raised bed and it covered the two rows of pigeonpea. The lateral spacing between two raised flat beds was $1.2 \mathrm{~m}$ and furrow inbetween with $30 \mathrm{~cm}$ width and $15 \mathrm{~cm}$ depth. Each treatment was supplied with an independent fertigation system consist of a drip tubes and controlled tapes. A tank filled with fertigation water was placed $1 \mathrm{~m}$ above the ground to maintain enough water pressure $1 \mathrm{~kg} / \mathrm{cm}^{2}$. Surface irrigation was given as and when cumulative pan evaporation (CPE) value reached the level of $83 \mathrm{~mm}$, which is in accordance with IW/CPE ratio of 0.60 .

Pigeonpea varieties viz. Co $(\mathrm{Rg}) 7\left(\mathrm{~V}_{1}\right)$, APK1 $\left(\mathrm{V}_{2}\right)$ and VBN3 $\left(\mathrm{V}_{3}\right)$ were selected. As per the treatments schedule, 75 percent of recommended dose of water soluble fertilizers $\left(\mathrm{V}_{1} \mathrm{~F}_{3}, \quad \mathrm{~V}_{2} \mathrm{~F}_{3}\right.$ and $\left.\mathrm{V}_{3} \mathrm{~F}_{3}\right), 100$ percent of recommended dose of water soluble fertilizers $\left(\mathrm{V}_{1} \mathrm{~F}_{2}, \mathrm{~V}_{2} \mathrm{~F}_{2}\right.$ and $\mathrm{V}_{3} \mathrm{~F}_{2}$ and $\mathrm{V}_{1} \mathrm{~F}_{4}, \mathrm{~V}_{2} \mathrm{~F}_{4}$ and $\mathrm{V}_{3} \mathrm{~F}_{4}$ ) and 125 percent of recommended dose of water soluble fertilizers $\left(\mathrm{V}_{1} \mathrm{~F}_{5}, \mathrm{~V}_{2} \mathrm{~F}_{5}\right.$ and $\mathrm{V}_{3} \mathrm{~F}_{5}$ ) were applied through the drip as per the fertigation schedule. The recommended doses of inorganic fertilizers @ 25:50:25 NPK kg $\mathrm{ha}^{-1}$ were applied through drip as per the fertigation schedule in the form of water soluble fertilizers viz., Mono Ammonium Phosphate (12:61\% N and P), Urea (46\% N), Poly feed (19:19:19\% NPK) and Sulphate of potash $(50 \% \mathrm{~K})$. The fertilizer solution was prepared by dissolving the required quantity of fertilizer with water in 1:5 ratio and injected into the irrigation system through venturi assembly. Fertigation interval was scheduled once in 7 days interval. The 
recommended doses (25:50:25 NPK kg ha $\left.{ }^{-1}\right)$ of inorganic fertilizers i.e., urea $(46 \% \mathrm{~N})$, single super phosphate $\left(\begin{array}{llll}16 & \% & \mathrm{P}_{2} \mathrm{O}_{5}\end{array}\right)$ and muriate of potash $\left(60 \% \mathrm{~K}_{2} \mathrm{O}\right)$ were applied as basal to the surface irrigated treatments $\left(\mathrm{V}_{1} \mathrm{~F}_{1}\right.$, $\mathrm{V}_{2} \mathrm{~F}_{1}$ and $\mathrm{V}_{2} \mathrm{~F}_{3}$ ) (GOTN, 2012). Plant samples collected for dry matter estimation at 60, 90, 120 DAS and at harvest stages from the respective treatments were oven-dried and finely ground in Willey mill and used for estimating $\mathrm{N}, \mathrm{P}$ and $\mathrm{K}$ content as per the standard procedure. Data were collected for pigeonpea dry matter production, nutrient uptake grain yield and straw yield at harvest stage. The nutrient content uptake values obtained as percentage in the analysis was multiplied by the respective dry matter content for computing $\mathrm{N}, \mathrm{P}$ and $\mathrm{K}$ uptake expressed in $\mathrm{kg} \mathrm{ha}^{-1}$.

Percentage of nutrient content $x$ Total dry matter production $\left(\mathrm{kg} \mathrm{ha}^{-1}\right)$ Nutrient uptake $\left(\mathrm{kg} \mathrm{ha}^{-1}\right)=$

\section{0}

\section{Results and Discussion}

\section{Dry matter production}

Drip fertigation at 125 per cent RDF through WSF with Azophosmet and $1 \%$ PPFM foliar spray followed by 100 per cent RDF through WSF with Azophosmet and $1 \%$ PPFM foliar spray recorded higher dry matter production (7042 and $6235 \mathrm{~kg} \mathrm{ha}^{-1}$ during kharif 2015 and summer 2016) as compared to surface irrigation with soil application of fertilizers.

This was mainly due to optimum moisture supply and timely nutrient application which could have enhanced the assimilatory efficiency resulting in increased number of leaves per plant, better branching and LAI which contributed for higher dry matter production as well as promoted the activity of photosynthesis and simultaneous accumulation of dry matter. Similar findings were recorded in banana for fertigation of 100 per cent RDF through drip as WSF by Sivalingam (2011). As the native soil was low in nitrogen, there was a good response to the excess fertilizer applied, coupled with optimum moisture availability which might have resulted in inducing growth in pigeonpea (Vimalendran, 2013). Dry matter production was favorably influenced by drip fertigation levels as compared to soil application of fertilizers with surface irrigation. Due to excess irrigation in surface irrigation methods, fertilizer nutrients might have been leached beyond the root zone, whereas in drip fertigation, fertilizers were applied through drip irrigation in desired split doses throughout the growing period according to crop requirements, so that the losses were minimized and opportunity was provided to take up more nutrients, which reflected on the higher plant growth rate and DMP Sathiyaraj (2010) (Table 1).

\section{Yield performance of pigeonpea under different fertigation levels}

Grain yield per hectare was significantly influenced by fertigation levels (Table 2). Drip irrigated pigeonpea with WSF recorded significantly higher grain yield during the experiment compared to surface method of irrigation. Among the three short duration pigeonpea varieties, Co ( $\mathrm{Rg}) 7$ performed well under arid condition compared to APK1 and VBN3. The variety Co $(\mathrm{Rg}) 7$ significantly registered highest grain yield of $1650 \mathrm{~kg} \mathrm{ha}^{-1}$, while APK 1 and VBN 3 registered significantly lower grain yield of 1301 and $1076 \mathrm{~kg} \mathrm{ha}^{-1}$. Among the drip fertigation levels, drip fertigation at 125 percent RDF through WSF with Azophosmet and foliar spray of PPFM registered significantly the highest grain yield of $1642 \mathrm{~kg} \mathrm{ha}^{-1}$, which was 74.3 percent yield increase over surface irrigation method with RDF through conventional method of application (942 kg $\mathrm{ha}^{-1}$ ). 
Table.1 Effect of drip fertigation levels on dry matter production and NPK uptake of short duration pigeonpea varieties

\begin{tabular}{|c|c|c|c|c|c|c|c|c|}
\hline \multirow[t]{2}{*}{ Treatments } & \multirow{2}{*}{$\begin{array}{l}\mathbf{2 0 1 5} \\
\text { DMP }\end{array}$} & \multirow{2}{*}{$\begin{array}{l}\mathbf{2 0 1 6} \\
\mathrm{DMP}\end{array}$} & \multicolumn{3}{|l|}{2015} & \multicolumn{3}{|l|}{2016} \\
\hline & & & $\begin{array}{l}\mathrm{N} \\
\text { uptake }\end{array}$ & $\begin{array}{l}\mathrm{P} \\
\text { uptake }\end{array}$ & $\begin{array}{l}\mathrm{K} \\
\text { uptake }\end{array}$ & $\begin{array}{l}\mathrm{N} \\
\text { uptake }\end{array}$ & $\begin{array}{l}\mathrm{P} \\
\text { uptake }\end{array}$ & $\begin{array}{l}\mathrm{K} \\
\text { uptake }\end{array}$ \\
\hline \multicolumn{9}{|l|}{ Varieties } \\
\hline $\mathrm{V}_{1}-\mathrm{Co}(\mathrm{Rg}) 7$ & 5850 & 5130 & 154.17 & 14.23 & 88.99 & 135.21 & 12.48 & 78.04 \\
\hline $\mathrm{V}_{2}$-APK 1 & 4665 & 4154 & 121.06 & 11.36 & 72.46 & 107.79 & 10.12 & 64.53 \\
\hline $\mathrm{V}_{3}-\mathrm{VBN} 3$ & 3876 & 3433 & 102.17 & 9.06 & 61.29 & 90.48 & 8.02 & 54.28 \\
\hline SEd & 117 & 158 & 3.19 & 0.33 & 2.37 & 2.85 & 0.29 & 2.37 \\
\hline CD (0.05) & 324 & 438 & 8.86 & 0.91 & 6.57 & 7.90 & 0.80 & 6.57 \\
\hline \multicolumn{9}{|l|}{ Fertigation } \\
\hline $\mathrm{F}_{1}$ & 3341 & 2997 & 87.22 & 7.93 & 51.32 & 78.24 & 7.11 & 46.04 \\
\hline $\mathrm{F}_{2}$ & 5053 & 4478 & 131.21 & 12.01 & 77.77 & 116.29 & 10.64 & 68.94 \\
\hline $\mathrm{F}_{3}$ & 4401 & 3915 & 115.03 & 10.84 & 68.01 & 102.32 & 9.63 & 60.53 \\
\hline $\mathrm{F}_{4}$ & 5305 & 4728 & 139.72 & 12.75 & 82.53 & 124.50 & 11.36 & 73.56 \\
\hline $\mathrm{F}_{5}$ & 5886 & 5079 & 155.82 & 14.22 & 91.62 & 134.45 & 12.28 & 79.02 \\
\hline SEd & 117 & 124 & 4.02 & 0.35 & 2.19 & 3.83 & 0.36 & 2.19 \\
\hline CD (0.05) & 270 & 287 & 2.27 & 0.80 & 5.06 & 8.82 & 0.84 & 5.06 \\
\hline \multicolumn{9}{|l|}{ Interaction } \\
\hline $\mathrm{V}_{1} \times \mathrm{F}_{1}$ & 4039 & 3598 & 106.23 & 9.57 & 60.99 & 94.63 & 8.53 & 54.33 \\
\hline $\mathrm{V}_{1} \times \mathrm{F}_{2}$ & 6149 & 5352 & 159.87 & 14.70 & 92.85 & 139.15 & 12.79 & 80.82 \\
\hline $\mathrm{V}_{1} \times \mathrm{F}_{3}$ & 5509 & 4727 & 144.89 & 14.21 & 83.74 & 124.32 & 12.20 & 71.85 \\
\hline $\mathrm{V}_{1} \times \mathrm{F}_{4}$ & 6512 & 5739 & 172.57 & 15.63 & 99.63 & 152.08 & 13.77 & 87.81 \\
\hline $\mathrm{V}_{1} \times \mathrm{F}_{5}$ & 7042 & 6235 & 187.32 & 17.04 & 107.74 & 165.85 & 15.09 & 95.40 \\
\hline $\mathrm{V}_{2} \times \mathrm{F}_{1}$ & 3187 & 2910 & 81.91 & 7.74 & 49.08 & 74.79 & 7.07 & 44.81 \\
\hline $\mathrm{V}_{2} \times \mathrm{F}_{2}$ & 5015 & 4468 & 129.89 & 12.04 & 77.73 & 115.72 & 10.72 & 69.25 \\
\hline $\mathrm{V}_{2} \times \mathrm{F}_{3}$ & 4220 & 3830 & 108.88 & 10.26 & 65.41 & 98.81 & 9.31 & 59.37 \\
\hline $\mathrm{V}_{2} \times \mathrm{F}_{4}$ & 5216 & 4662 & 135.62 & 12.78 & 81.37 & 121.21 & 11.42 & 72.73 \\
\hline $\mathrm{V}_{2} \times \mathrm{F}_{5}$ & 5687 & 4902 & 149.00 & 13.99 & 88.72 & 128.43 & 12.06 & 76.47 \\
\hline $\mathrm{V}_{3} \times \mathrm{F}_{1}$ & 2796 & 2483 & 73.54 & 6.46 & 43.90 & 65.30 & 5.74 & 38.98 \\
\hline $\mathrm{V}_{3} \times \mathrm{F}_{2}$ & 3995 & 3615 & 103.87 & 9.31 & 62.72 & 93.99 & 8.42 & 56.76 \\
\hline $\mathrm{V}_{3} \times \mathrm{F}_{3}$ & 3473 & 3187 & 91.34 & 8.06 & 54.87 & 83.82 & 7.39 & 50.36 \\
\hline $\mathrm{V}_{3} \times \mathrm{F}_{4}$ & 4188 & 3782 & 110.98 & 9.84 & 66.59 & 100.22 & 8.89 & 60.13 \\
\hline $\mathrm{V}_{3} \times \mathrm{F}_{5}$ & 4930 & 4100 & 131.14 & 11.64 & 78.39 & 109.06 & 9.68 & 65.19 \\
\hline SEd & 151 & 141 & 3.40 & 0.33 & 2.13 & 3.39 & 0.32 & 1.70 \\
\hline $\mathrm{CD}(0.05)$ & 321 & 299 & 7.20 & 0.71 & 4.52 & 7.19 & 0.67 & 3.61 \\
\hline
\end{tabular}


Table.2 Effect of drip fertigation levels on yield and yield attributes of short duration pigeonpea varieties

\begin{tabular}{|c|c|c|c|c|c|c|}
\hline \multirow[t]{2}{*}{ Treatments } & \multicolumn{3}{|c|}{2015} & \multicolumn{3}{|c|}{2016} \\
\hline & $\begin{array}{c}\text { Grain } \\
\text { yield (kg } \\
\left.\text { ha }^{-1}\right)\end{array}$ & $\begin{array}{l}\text { Stalk yield } \\
\left(\mathrm{kg} \mathrm{ha}^{-1}\right)\end{array}$ & $\begin{array}{c}\text { Harvest } \\
\text { Index }\end{array}$ & $\begin{array}{l}\text { Grain yield } \\
\left(\mathrm{kg} \mathrm{ha}^{-1}\right)\end{array}$ & $\begin{array}{c}\text { Stalk } \\
\text { yield (kg } \\
\left.\mathrm{ha}^{-1}\right)\end{array}$ & $\begin{array}{c}\text { Harvest } \\
\text { Index }\end{array}$ \\
\hline \multicolumn{6}{|c|}{ Varieties } & \\
\hline $\mathrm{V}_{1}-\mathrm{Co}(\mathrm{Rg}) 7$ & 1650 & 3872 & 30.19 & 1449 & 3333 & 30.24 \\
\hline $\mathrm{V}_{2}$-APK 1 & 1301 & 2941 & 29.88 & 1175 & 2740 & 29.98 \\
\hline $\mathrm{V}_{3}$-VBN 3 & 1076 & 2484 & 29.71 & 968 & 2281 & 29.75 \\
\hline SEd & 41 & 69 & 0.75 & 30 & 83 & 0.753 \\
\hline CD (0.05) & 116 & 191 & $\mathrm{~ns}$ & 83 & 230 & ns \\
\hline \multicolumn{7}{|l|}{$\begin{array}{c}\text { Fertigation } \\
\text { levels }\end{array}$} \\
\hline $\mathrm{F}_{1}$ & 942 & 2143 & 29.58 & 852 & 2025 & 29.59 \\
\hline $\mathrm{F}_{2}$ & 1414 & 3239 & 29.91 & 1267 & 2956 & 29.98 \\
\hline $\mathrm{F}_{3}$ & 1235 & 2876 & 29.72 & 1111 & 2615 & 29.79 \\
\hline $\mathrm{F}_{4}$ & 1479 & 3418 & 30.07 & 1325 & 3060 & 30.19 \\
\hline $\mathrm{F}_{5}$ & 1642 & 3819 & 30.36 & 1431 & 3267 & 30.41 \\
\hline SEd & 31 & 59 & 0.42 & 33 & 60 & 0.42 \\
\hline CD (0.05) & 71 & 136 & ns & 77 & 138 & $\mathrm{~ns}$ \\
\hline \multicolumn{6}{|c|}{ Varieties $\times$ Fertigation } & \\
\hline $\mathrm{V}_{1} \times \mathrm{F}_{1}$ & 1145 & 2704 & 29.76 & 1022 & 2425 & 29.64 \\
\hline $\mathrm{V}_{1} \times \mathrm{F}_{2}$ & 1731 & 4007 & 30.12 & 1512 & 3490 & 30.23 \\
\hline $\mathrm{V}_{1} \times \mathrm{F}_{3}$ & 1556 & 3656 & 29.94 & 1348 & 3140 & 30.04 \\
\hline $\mathrm{V}_{1} \times \mathrm{F}_{4}$ & 1827 & 4254 & 30.30 & 1606 & 3680 & 30.38 \\
\hline $\mathrm{V}_{1} \times \mathrm{F}_{5}$ & 1992 & 4740 & 30.83 & 1758 & 3930 & 30.91 \\
\hline $\mathrm{V}_{2} \times \mathrm{F}_{1}$ & 898 & 2001 & 29.59 & 821 & 1940 & 29.64 \\
\hline $\mathrm{V}_{2} \times \mathrm{F}_{2}$ & 1399 & 3134 & 29.85 & 1268 & 2975 & 30.23 \\
\hline $\mathrm{V}_{2} \times \mathrm{F}_{3}$ & 1184 & 2711 & 29.74 & 1085 & 2545 & 30.04 \\
\hline $\mathrm{V}_{2} \times \mathrm{F}_{4}$ & 1451 & 3268 & 30.04 & 1308 & 3030 & 30.38 \\
\hline $\mathrm{V}_{2} \times \mathrm{F}_{5}$ & 1574 & 3589 & 30.17 & 1392 & 3210 & 30.91 \\
\hline $\mathrm{V}_{3} \times \mathrm{F}_{1}$ & 783 & 1724 & 29.40 & 712 & 1710 & 29.40 \\
\hline $\mathrm{V}_{3} \times \mathrm{F}_{2}$ & 1111 & 2577 & 29.75 & 1021 & 2403 & 29.82 \\
\hline $\mathrm{V}_{3} \times \mathrm{F}_{3}$ & 966 & 2260 & 29.49 & 901 & 2160 & 29.43 \\
\hline $\mathrm{V}_{3} \times \mathrm{F}_{4}$ & 1158 & 2733 & 29.86 & 1060 & 2470 & 30.03 \\
\hline $\mathrm{V}_{3} \times \mathrm{F}_{5}$ & 1360 & 3128 & 30.07 & 1144 & 2660 & 30.07 \\
\hline SEd & 52 & 83 & 0.78 & 34 & 92 & 0.783 \\
\hline CD (0.05) & 110 & 176 & $\mathrm{~ns}$ & 72 & 194 & ns \\
\hline
\end{tabular}


Fig.1 Effect of drip fertigation levels on $\mathrm{N}, \mathrm{P}_{2} \mathrm{O}_{5}$ and $\mathrm{K}_{2} \mathrm{O}$ uptake $\left(\mathrm{kg} \mathrm{ha}^{-1}\right)$ of pigeonpea varieties

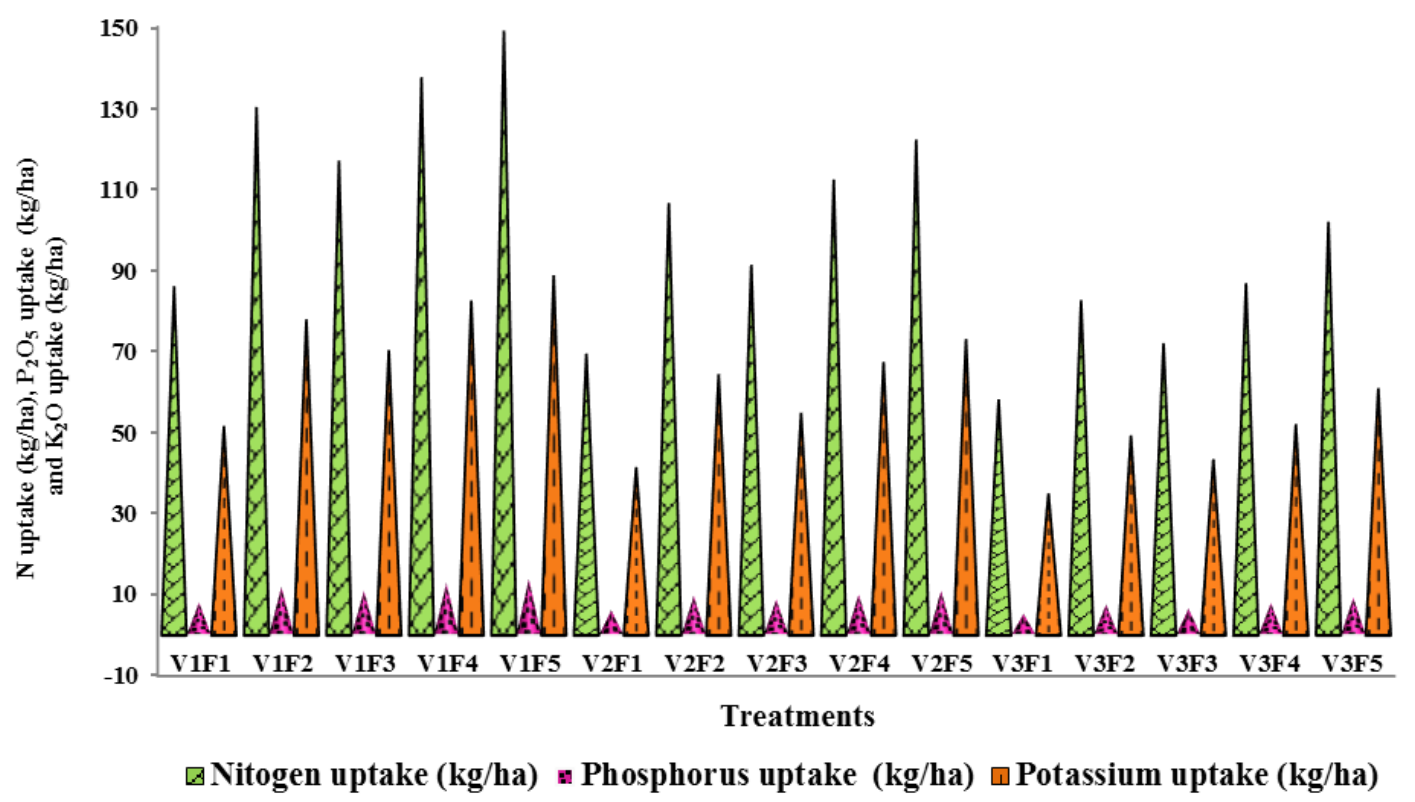

Among the drip fertigation levels and varieties, variety of $\mathrm{Co}(\mathrm{Rg}) 7$ with drip fertigation at 125 percent RDF through WSF with Azophosmet and foliar spray of PPFM significantly registered highest grain yield of $1992 \mathrm{~kg} \mathrm{ha}^{-1}$. The result on stalk yield also indicated significant difference as that of grain yield. The pigeonpea variety of Co $(\mathrm{Rg}) 7$ with drip fertigation at 125 percent RDF through WSF with Azophosmet and foliar spray of PPFM significantly registered highest stalk yield of $4740 \mathrm{~kg} \mathrm{ha}^{-1}$.

\section{Nutrient uptake}

The higher nitrogen uptake of 17.46, 63.58, 124.47 and $155.82 \mathrm{~kg} \mathrm{ha}^{-1}$ during kharif 2015 and $15.15,54.66,108.37$ and $134.45 \mathrm{~kg} \mathrm{ha}^{-1}$ during summer 2016 were observed under fertigation with 125 per cent RDF through WSF with the concentration and availability of various nutrients in the soil for plant uptake depends on the soil solution phase, which is mainly determined by the soil moisture availability (Fig. 1). The higher available soil moisture, provided by continuous water supply under drip irrigation, had led to higher availability of nutrients in the soil and thereby increased the nutrient uptake by the crop. The availability of $\mathrm{N}, \mathrm{P}$ and $\mathrm{K}$ nutrient was higher in root zone area of drip feritgated plot which in turn increased the uptake of nutrients (Sathya et al., 2008). Similar findings of higher nutrient uptake with drip fertigation over soil application of nutrients were also reported in hybrid cotton by Veeraputhiran (2000). In the conventional method of fertilizer application with surface irrigation, nutrients were applied only to the top soil layer. This layer was subjected to alternate drying and wetting cycles due to longer irrigation intervals. Low soil-water content as well as higher fixation with soil colloids and lesser mobility had reduced the availability of applied nutrients. Similar absorption pattern with varying irrigation methods was narrated by Escobar (1995). Lower uptake was observed with surface irrigation with soil application of fertilizers. However, this treatment resulted in higher uptake of nutrients at vegetative stage due to surface application of fertilizers. Jayakumar et al., 
(2014) reported that drip fertigation with 150 per cent recommended dose of NPK and biofertigation was significantly superior in nutrient uptake with the highest $\mathrm{N}, \mathrm{P}$ and $\mathrm{K}$ uptake of $110.9,28.2$ and $110.6 \mathrm{~kg}$ ha-1 at 120 DAS, respectively.

\section{Yield performance at drip fertigation levels as compared to conventional fertilizer}

The yield with Co $(\mathrm{Rg}) 7$ under drip fertigation at 125 per cent RDF through WSF with Azophosmet and foliar spray of 1\% PPFM was 15.1 to 16.3 per cent higher than drip fertigation at 100 per cent RDF through WSF and 72.0 to 74.0 per cent higher than surface irrigation with the application of conventional fertilizer. The yield increases of pigeonpea with 125 percent RDF through WSF might be due to the fact that fertigation at higher dose obliviously resulted in higher availability of all three major nutrients (NP and $\mathrm{K}$ ) in the soil solution, which led to higher uptake and better translocation of assimilates from source to sink, thus in turn increased the yield. Similar linear response to higher doses of fertilizer was obtained in long duration pigeonpea under drip fertigation by Vimalendren and Latha (2014). The yield attributing characters of pigeonpea were higher under drip irrigation with fertigation at 125 percent RDF through WSF because better crop growth at higher nutrient levels might have influenced the yield favorably. These results were accordance with the findings of Jeetendra Kumar Soni (2015). Under drip fertigation, the WSF were applied at the site of high concentration of active roots with more number of splits i.e once in seven days up to reproductive stage which might have resulted in higher availability and higher uptake by the roots and ultimately resulted in higher yield characters and yield of the crop. Whereas in the surface applied plots, the fertilizers were applied in excess on the soil with minimum number of splits i.e., one basal for pigeonpea. So the availability of nutrients would be very high during first 20-30 days, which have resulted in higher growth parameters during that stage, but at reproductive stage the applied nutrients would have been depleted or leached off and not available to the crops which might have resulted in lower yield attributing characters and yield of the crops. Similar findings of higher yield under drip irrigated crops were observed by Sampathkumar et al., (2006). The perusal of the yield data showed the favourable effect of drip fertigation on yield of pigeonpea. The yield per hectare was significantly improved by the application of major nutrients through fertigation which boosted the overall vegetative growth and biological efficiency of the plant. Another plausible reason was the timely availability of nutrients during the flower production which favorably increases the number of flowers plant. Better crop growth at higher nutrient levels might have influenced the yield attributes favorably. The increase in yield might be due to better proportion of air-soilwater which was maintained throughout the life period of crop in drip irrigation as compared to surface irrigation as reported by Khalil Ajdary (2007).

Increased drymatter production, nutrient uptake, seed yield per ha ${ }^{-1}$ and stalk yield per ha $^{-1}$ relative to 125 percent RDF through WSF under drip fertigation. This is important for understanding the impacts of different fertigation regimes compared to surface irrigation regimes. The findings of the foregoing experiments have clearly established that fertigation is definitely advantageous over the surface irrigation with basal application of fertilizers.

\section{References}

Anitta Fanish, S., P. Muthukrishnan, and P. Ayyadurai. 2013. Root characters of 
maize as influenced by drip fertigation levels. American J Plant Sci., 4: 340348.

Escobar, R.N. 1995. Development and present status of fertigation in Mexico. In: Proc. Dahlia Greidinger International Symposium of fertigaiton. March 26, April 1, Israel, pp. 287-296.

GoI. 2015. Agricultural Statistics at a Glance 2015. Directorate of Economics and Statistics, Department of Agriculture, Cooperation and Farmers Welfare, Ministry of Agriculture and Farmers Welfare, Krishi Bhawan, New Delhi.

Jayakumar, M., U. Surendran and P. Manickasundaram. 2014. Drip fertigation effects on yield, nutrient uptake and soil fertility of Bt Cotton in semi arid tropics. Int. J. Plant Production., 8(3): 375-390.

Jeetendra Kumar Soni. 2015. Performance evaluation of drip and micro sprinkler fertigation system in groundnut (TMV13). M.Sc. (Agri.). Thesis, Tamil Nadu Agricultural University, Coimbatore.

Kadam, J.R., Karthikeyan, S., 2006. Effect of soluble NPK fertilizers on the nutrient balance, water use efficiency, fertilizer use efficiency of drip system in a Tomato. Int. J. Plant Sci. 1, 92-94.

Pramod, G., B.T. Pujari, M.K. Basavaraja, V. Mahantesh and V. Gowda. 2010. Yield, yield parameters and economics of pigeonpea (Cajanus cajan (L.) Millsp.) as influenced by genotypes, planting geometry and protective irrigation. Int. J. Agric. Sci., 6(2): 422-425.
Sampathkumar, T., S. Krishnasamy, K. Ramesh and K. Shanmugasundaram. 2006. Effect of drip and surface irrigation methods with rice straw mulch on productivity and water use efficiency of summer cotton. Crop Res., 32(2): 141-144.

Sathiyaraj, M. 2010. Study on the influence of irrigation regimes and fertigation levels on sugarcane under subsurface drip fertigation system. Ph.D. Thesis. Tamil Nadu Agric. Univ., Madurai.

Sathya, S.G., James Pitchai, R. Indirani and M. Kannathasan. 2008. Effect of fertigation on availability of nutrients $(\mathrm{N}, \mathrm{P}$ and $\mathrm{K})$ in soil- A review. Agric. Rev., 29 (3): 214 - 219.

Sivalingam, G. 2011. Effect of sources and method of nutrient application for banana under drip fertigation system. M.Sc. (Ag.), Thesis. Tamil Nadu Agric. Univ., Madurai.

Tarawalie, I. F., Wengang, X., Guangcheng, S. and Chunli, H. (2012). Effect of water use efficiency on growth and yield of hot pepper under partial rootzone drip irrigation condition. International Journal of Scientific and Engineering Research, 3(1): 1-13

Veeraputhiran, R. 2000. Drip fertigation studies in hybrid cotton. Ph.D. Thesis, Tamil Nadu Agric. Univ. Coimbatore.

Vimalendran. L. and K.R. Latha. 2014. Yield, water use and water use efficiency of pigeonpea [Cajanus cajan (L.) Millsp.] under drip fertigation system. JANS, 6(1): 457-462.

\section{How to cite this article:}

Jeyajothi, R. and Pazhanivelan, S. 2017. Dry matter, Nutrient Uptake and Yield of Short Duration Pigeon pea (Cajanus cajan L.) Varieties under Drip Fertigation system. Int.J.Curr.Microbiol.App.Sci. 6(11): 3958-3965. doi: https://doi.org/10.20546/ijcmas.2017.611.462 